I.М. Коржов ${ }^{1}$, Я.О. Кравченко ${ }^{2}$, Є.А. Борисенко ${ }^{2}$

${ }^{1}$ Державне підприємство "Харківський регіональний науково-виробничий иенттр стандартизації, метрології та сертифікації" Харків

${ }^{2}$ Національний технічний університет "Харківський політехнічний інститут", Харків

\title{
АНАЛІЗ ОСНОВНИХ СКЛАДОВИХ ПОХИБКИ ВИЗНАЧЕННЯ ТВЕРДОСТІ ЗА МЕТОДОМ БРІНЕЛЛЯ 3 ВИКОРИСТАННЯМ ОПТИЧНИХ СИСТЕМ
}

У статті приведено загальний алгоритм для визначення твердості за Брінеллем для вимірювальних приладів з оптичною системою на основі положень міжнародного стандарту ISO 6506, отримана результуюча формула для розрахунку твердості за Брінеллем для вимірювальних приладів з оптичною системою. На основі результуючої формули для розрахунку твердості отримані та проаналізовані абсолютна та відносна похибка, а також їх складові. Наведено теоретичний аналіз основних величин, щяо впливають на точність визначення твердості за методом Брінелля та шляхи їх зменшення для вимірювальних приладів з програмним забезпеченням для розрахунків та оптичною системою для вимірювання параметрів відбитку індентора. Приведений теоретичний аналіз складових похибок визначення твердості за методом Брінелля та иляхи їх зменшення, дають змогу більш детально оцінити похибку визначення твердості та мінімізувати вплив деяких складових відповідного устаткування для вимірювання твердості.

Ключові слова: твердість, метод Брінелля, твердоміри з оптичною системою, метрологічне забезпечення, аналіз похибки.

\section{Вступ}

Постановка проблеми. У зв'язку з постійним підвищенням вимог до якості промислової продукції, як на вітчизняному так і на світовому ринку, відбувається постійне посилення умов контролю вхідної сировини, у тому числі металу та металевих виробів, що в свою чергу призводить до необхідності ретельного метрологічного забезпечення контролю вхідної сировини в цілому і зокрема визначення твердості металу та металевих виробів.

У міжнародному стандарті ISO 6506 (стандартизує всі значні аспекти визначення твердості металевих виробів за методом Брінелля), що складається 3 чотирьох частин [1-4] не в повній мірі розкриті величини, що впливають на точність вимірювання, та шляхи їх зменшення для вимірювальних приладів 3 використанням програмного забезпечення для розрахунків та оптичних систем для автоматизованого вимірювання параметрів відбитку індентора, які набирають популярності серед профільних випробувальних лабораторій.

Аналіз останніх досліджень і публікацій. Твердість є однією з фізико-механічних властивостей конструкційних матеріалів що визначає ї якість, особливо це справедливо для металів та їх сплавів. Твердість це спроможність матеріалу опиратися деформуванню та, як наслідок, руйнуванню. За твердістю металу можливо опосередковано оцінювати інші його властивості, у зв'язку із залежністю твердості від внутрішньої структури матеріалу. Існують десятки різноманітних методів визначення твердості мета- лів та їх сплавів, серед найбільш поширених слід виділити методи Віккерса, Роквелла та Брінелля. Всі три методи засновані на контрольованому вдавлюванні спеціального індентора та вимірюванні залишеного ним відбитку. За зазначеними методами визначають статичну твердість металів та їх сплавів у більшості сфер промисловості [5-12].

Існуюче метрологічне забезпечення визначення твердості металевих виробів за методом Брінелля регламентує міжнародний стандарт ISO 6506 [1-4]. Зазначений стандарт у повній мірі нормує проведення вимірювання твердості, проведення повірки та калібрування застосовуваних при вимірюванні твердості засобів вимірювальної техніки. Про значимість метрологічного забезпечення визначення твердості металевих виробів опосередковано свідчить регулярність перегляду частин зазначеного стандарту, наприклад, на момент написання статті актуальною є четверта редакція другої частини стандарту [1-4].

Мета статті полягає в аналізі основних величин, що впливають на точність визначення твердості за методом Брінелля та шляхи їх зменшення для вимірювальних приладів 3 використанням програмного забезпечення для розрахунків та оптичних систем для вимірювання параметрів відбитку індентора.

\section{Виклад основного матеріалу}

\section{Загальний опис визначення твердості за методом Брінелля}

Визначення твердості за методом Брінелля полягає у вдавленні індентора (полірованої кульки 3 
твердого металу діаметром $D)$ у поверхню зразка (матеріалу, твердість якого потрібно визначити), а потім, після зняття зусилля $F$ через час $t$, вимірюють середній діаметр відбитка $d$ (як середнє арифметичне двох виміряних перпендикулярних діаметрів), який залишився на поверхні. Твердість за Брінеллем пропорційна результату від ділення числового значення величини випробувального зусилля $F$ на числове значення площі сферичної поверхні відбитка (приймається, що відбиток зберігає форму кульки, а його поверхню обчислюють за значенням середнього діаметра відбитка і діаметра індентора) [5-12].

Схема позначення визначеної твердості за методом Брінелля (згідно з ISO 6506) представлена на рис. 1, також замість позначення "HBW" зустрічаються "НВ" та "HBS" [1-4].

Схематичне представлення методу та загальний алгоритм визначення твердості за Брінеллем для вимірювальних приладів 3 оптичною системою створено на основі математичного апарату, що викладено у ISO 6506 та зображено на рис. 2 [1-4].

\section{Юстування оптичної системи та введення параметрів випробування}

Перед проведенням випробування необхідно провести юстування оптичної системи, яке полягає в визначенні “довжини пікселя”, $l_{p}$ за допомогою об'єкт мікрометру. “Довжина пікселя”, $l_{p}$ - довжина фізичної поверхні що відповідає одному пікселю (найменшому логічному елементу) двомірного цифрового зображення, що отримане оптичною системою [5-12].

“Довжина пікселя" $l_{p}$ при юстуванні визначається за допомогою “вимірювання” об’єкт мікрометру за формулою:

$$
l_{p}=\frac{l_{\text {oм }}}{n_{p}},
$$

де $l_{\text {ом }}$ - довжина об'єкт-мікрометру, що використовується при юстуванні, мм;

$n_{p}$ - кількість пікселів на отриманому оптичною системою цифровому зображенні, що відповідають довжині об'єкт мікрометру $\left(l_{\text {ом }}\right)$.

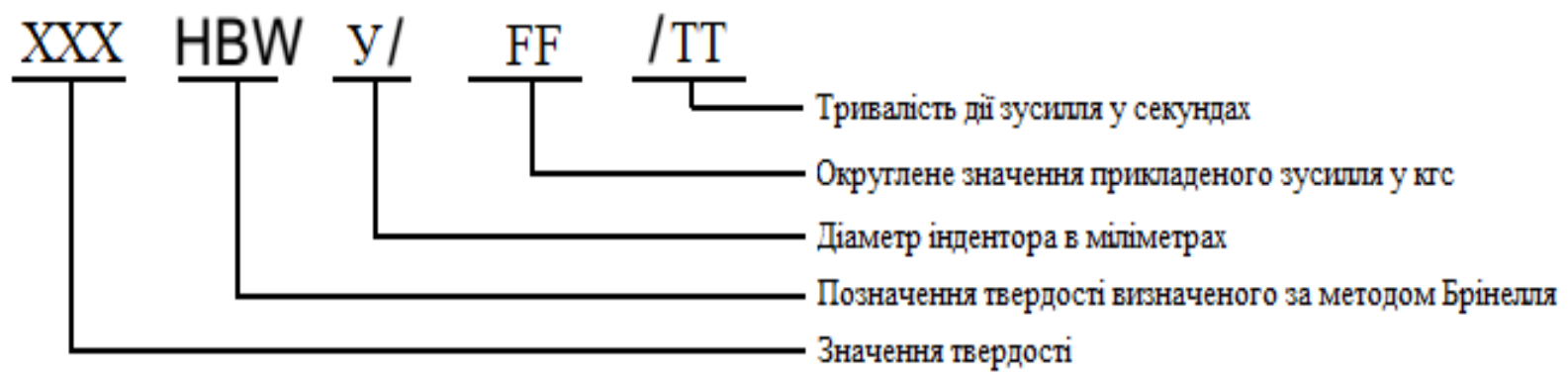

Рис. 1. Схема позначення визначеної твердості за методом Брінелля Джерело: розроблено авторами за даними [1-4].
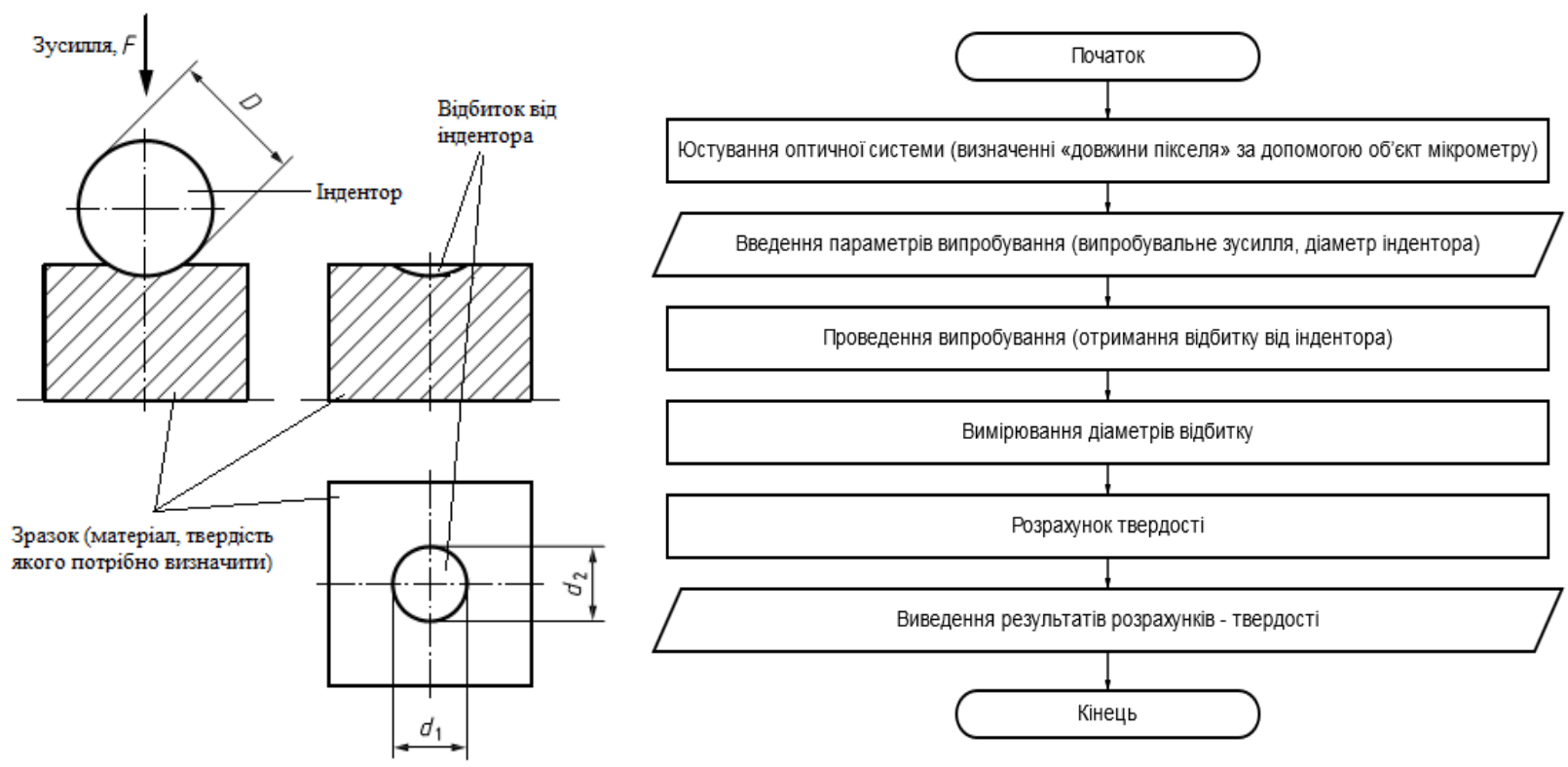

Рис. 2. Схема методу та загальний алгоритм визначення твердості за Брінеллем для вимірювальних приладів з оптичною системою Джерело: розроблено авторами за даними [1-4]. 
Також перед проведенням випробування слід визначитися з необхідним параметрами, а саме, випробувальне зусилля $F$ (кгс) та діаметр індентора $D$ (мм), вибір зазначених параметрів слід проводити опираючись на положення ISO 6506 та матеріал зразка, твердість якого визначається, тобто слід апріорі оцінити діапазон твердості, в якому знаходиться зразок. В інакшому випадку можливі значні похибки та труднощі з вимірюванням середнього діаметру відбитку та виникнення необхідності повторення випробовування $з$ іншими параметрами [1-4]. Для переводу випробувального зусилля заданого у Ньютонах $(\mathrm{H})$ до кілограм-сили (кгс) застосовують формулу:

$$
F=\frac{F_{H}}{k},
$$

де $F_{H}$ - випробувальне зусилля задане в $\mathrm{H}$;

$k$-коефіцієнт перерахунку зусилля кг.с в $\mathrm{H}$ $(k=9,80665$ [точно] $\mathrm{H} /$ кг $\cdot \mathrm{c})$.

\section{Вимірювання діаметрів відбитку d1 та d2 та розрахунок твердості}

Вимірювання діаметрів відбитку $d_{1}$ та $d_{2}$ проводиться або вручну оператором, який виставляє горизонтальні та вертикальні маркери на границях відбитку або автоматично за допомогою спеціалізованого програмного забезпечення. В будь-якому випадку за допомогою підрахунку кількості пікселів між визначеними маркерами розраховується фізична довжина діаметрів відбитку $d_{1}$ та $d_{2}$ за формулами:

$$
\begin{aligned}
& d_{1}=n_{1} l_{p} ; \\
& d_{2}=n_{2} l_{p},
\end{aligned}
$$

де $n_{1}, n_{2}$ - кількість пікселів між горизонтальними та вертикальними маркерами. Згідно 3 ISO 6506 [1 - 4]:

1) середній діаметр відбитку $d$, мм $\epsilon$ середнє арифметичне виміряних діаметрів відбитку $d_{1}$ та $d_{2}$ :

$$
d=\frac{d_{1}+d_{2}}{2} .
$$

2) остаточна формула розрахунку значення твердості, $H B W$ :

$$
H B W=\frac{1}{k} \cdot \frac{2 F_{H}}{\pi D^{2}\left(\sqrt{1-\frac{d^{2}}{D^{2}}}\right)} .
$$

Після підстановки (1-5) у (6) отримаємо результуючу формулу для розрахунку твердості за Брінеллем:

$$
H B W=\frac{2 F_{H}}{\pi \cdot k \cdot D^{2} \cdot \sqrt{1-\frac{\left(\frac{l_{O M}\left(n_{1}+n_{2}\right)}{2 n_{p}}\right)^{2}}{D^{2}}} .}
$$

Розрахунок абсолютної похибки визначення твердості

Результуюча формула (7) дає змогу оцінити абсолютну похибку $\Delta$ визначення твердості за Брінеллем

$$
\Delta=\sqrt{\left(\begin{array}{l}
\left(\frac{\partial H B W}{\partial F_{H}} \Delta_{F_{H}}\right)^{2}+\left(\frac{\partial H B W}{\partial \pi} \Delta_{\pi}\right)^{2}+ \\
+\left(\frac{\partial H B W}{\partial k} \Delta_{k}\right)^{2}+\left(\frac{\partial H B W}{\partial D} \Delta_{D}\right)^{2}+ \\
+\left(\frac{\partial H B W}{\partial l_{O M}} \Delta_{l_{o M}}\right)^{2}+\left(\frac{\partial H B W}{\partial n_{1}} \Delta_{n_{1}}\right)^{2}+ \\
+\left(\frac{\partial H B W}{\partial n_{2}} \Delta_{n_{2}}\right)^{2}+\left(\frac{\partial H B W}{\partial n_{p}} \Delta_{n_{p}}\right)^{2}
\end{array}\right.},
$$

де $\Delta_{F_{H}}$ - абсолютна похибка визначення випробувального зусилля $F_{H}$ у H;

$\Delta_{\pi}$ - абсолютна похибка визначення числа $\pi$ при розрахунках;

$\Delta_{k}$ - абсолютна похибка визначення коефіцієнта перерахунку кг.с в $\mathrm{H} k$;

$\Delta_{D}$ - абсолютна похибка визначення діаметра індентора $D$;

$\Delta_{l_{\text {oм }}}$ - абсолютна похибка визначення довжини об'єкт мікрометру, $l_{o м}$, що задана при юстуванні системи;

$\Delta_{n_{1}}$ - абсолютна похибка визначення кількості пікселів між горизонтальними маркерами, $n_{1}$;

$\Delta_{n_{2}}$ - абсолютна похибка визначення кількості пікселів між вертикальними маркерами, $n_{2}$;

$\Delta_{n_{p}}$ - абсолютна похибка визначення кількості пікселів, $n_{p}$, на отриманому цифровому зображенні, що відповідають заданій довжині об'єкт мікрометру $\left(l_{o м}\right)$, юстування фотометричної системи;

$$
\frac{\partial H B W}{\partial F_{H}} \text { - часткова похідна результуючої фор- }
$$
мули (7) за випробувальним зусиллям $F_{H}$ у $\mathrm{H}$ :

$$
\frac{\partial H B W}{\partial F_{H}}=\frac{2}{\pi \cdot k \cdot D^{2} \cdot \sqrt{1-\frac{\left(\frac{l_{O M}\left(n_{1}+n_{2}\right)}{2 n_{p}}\right)^{2}}{D^{2}}}},
$$

де $\frac{\partial H B W}{\partial \pi}-$ часткова похідна результуючої формули (7) за числом $\pi$ (число $\pi$ задається 3 кінцевою кількістю цифр після коми, що вносить похибку [13-17]): 


$$
\frac{\partial H B W}{\partial \pi}=-\frac{2 F_{H}}{\pi^{2} \cdot k \cdot D^{2} \cdot \sqrt{1-\frac{\left(\frac{l_{O M}\left(n_{1}+n_{2}\right)}{2 n_{p}}\right)^{2}}{D^{2}}}},(10)
$$

де $\frac{\partial H B W}{\partial k}-$ часткова похідна результуючої формули (7) за коефіцієнтом перерахунку кгс в Н $k$ (число $k$ задається з кінцевою кількістю цифр після коми, що може вносити похибку [13 - 17]):

$$
=-\frac{\frac{\partial H B W}{\partial k}=}{\pi \cdot k^{2} \cdot D^{2} \cdot \sqrt{1-\frac{\left(\frac{l_{O M}\left(n_{1}+n_{2}\right)}{2 n_{p}}\right)^{2}}{D^{2}}}},
$$

де $\frac{\partial H B W}{\partial D}-$ часткова похідна результуючої формули (7) за діаметром індентора $D$ :

$$
\begin{gathered}
\frac{\partial H B W}{\partial D}=-\frac{4 F_{H}}{\pi \cdot k \cdot D^{3} \cdot \sqrt{1-\frac{\left(\frac{l_{O M}\left(n_{1}+n_{2}\right)}{2 n_{p}}\right)^{2}}{D^{2}}}}- \\
-\frac{F_{H} \cdot l_{O M}^{2} \cdot\left(n_{1}+n_{2}\right)^{2}}{2 \pi \cdot k \cdot D^{5} \cdot n_{p}^{2} \cdot\left(1-\frac{\left(\frac{l_{O M}\left(n_{1}+n_{2}\right)}{2 n_{p}}\right)^{2}}{D^{2}}\right)^{\frac{3}{2}}},
\end{gathered}
$$

де $\frac{\partial H B W}{\partial l_{\text {oм }}}$ - часткова похідна (7) за діаметром довжиною об'єкт мікрометру, $l_{o м}$, що задана оператором при юстуванні фотометричної системи:

$$
\begin{gathered}
\frac{\partial H B W}{\partial l_{O M}}= \\
\frac{F_{H} \cdot l_{O M}\left(n_{1}+n_{2}\right)^{2}}{2 \pi \cdot k \cdot D^{4} \cdot n_{p}^{2} \cdot\left(1-\frac{\left(\frac{l_{O M}\left(n_{1}+n_{2}\right)}{2 n_{p}}\right)^{2}}{D^{2}}\right)^{\frac{3}{2}}},
\end{gathered}
$$

де $\frac{\partial H B W}{\partial n_{1}}$ - часткова похідна (7) за кількістю пікселів між горизонтальними маркерами, $n_{1}$ :

$$
\frac{\partial H B W}{\partial n_{1}}=\frac{F_{H} \cdot l_{o M}^{2}\left(2 n_{1}+2 n_{2}\right)}{4 \pi \cdot k \cdot D^{4} \cdot n_{p}^{2} \cdot\left(1-\frac{\left(\frac{l_{O M}\left(n_{1}+n_{2}\right)}{2 n_{p}}\right)^{2}}{D^{2}}\right)^{\frac{3}{2}}}
$$

де $\frac{\partial H B W}{\partial n_{2}}$ - часткова похідна результуючої формули (7) за кількістю пікселів між вертикальними маркерами:

$$
\frac{\partial H B W}{\partial n_{2}}=\frac{F_{H} \cdot l_{O M}^{2}\left(2 n_{1}+2 n_{2}\right)}{4 \pi \cdot k \cdot D^{4} \cdot n_{p}^{2} \cdot\left(1-\frac{\left(\frac{l_{O M}\left(n_{1}+n_{2}\right)}{2 n_{p}}\right)^{2}}{D^{2}}\right)^{\frac{3}{2}}}
$$

де $\frac{\partial H B W}{\partial n_{p}}-$ часткова похідна результуючої формули (7) за кількістю пікселів, $n_{p}$, на отриманому цифровому зображенні, що відповідають заданій довжині об'єкт мікрометру $\left(l_{\text {oм }}\right)$, при юстуванні фотометричної системи:

$$
\frac{\partial H B W}{\partial n_{p}}=-\frac{F_{H} \cdot l_{O M}^{2}\left(n_{1}+n_{2}\right)^{2}}{2 \pi \cdot k \cdot D^{4} \cdot n_{p}^{3} \cdot\left(1-\frac{\left(\frac{l_{O M}\left(n_{1}+n_{2}\right)}{2 n_{p}}\right)^{2}}{D^{2}}\right)^{\frac{3}{2}}} .
$$

\section{Розрахунок відносної похибки визначення твердості}

Відносна похибка при визначенні твердості за Брінеллем, $\delta$ :

$$
\begin{aligned}
& \Delta=\left(\left(\frac{\partial \ln H B W}{\partial F_{H}} \Delta_{F_{H}}\right)^{2}+\left(\frac{\partial \ln H B W}{\partial \pi} \Delta_{\pi}\right)^{2}+\right. \\
& +\left(\frac{\partial \ln H B W}{\partial k} \Delta_{k}\right)^{2}+\left(\frac{\partial \ln H B W}{\partial D} \Delta_{D}\right)^{2}+ \\
& +\left(\frac{\partial \ln H B W}{\partial l_{O M}} \Delta_{l_{O M}}\right)^{2}+\left(\frac{\partial \ln H B W}{\partial n_{1}} \Delta_{n_{1}}\right)^{2}+ \\
& \left.+\left(\frac{\partial \ln H B W}{\partial n_{2}} \Delta_{n_{2}}\right)^{2}+\left(\frac{\partial \ln H B W}{\partial n_{p}} \Delta_{n_{p}}\right)^{2}\right)^{\frac{1}{2}}
\end{aligned}
$$

де $\frac{\partial \ln H B W}{\partial F_{H}}$ - часткова похідна натурального ло- 
гарифму результуючої формули (7) за випробувальним зусиллям $F_{H}$ у Н:

$$
\frac{\partial \ln H B W}{\partial F_{H}}=\frac{1}{F_{H}}
$$

де $\frac{\partial \ln H B W}{\partial \pi}-$ часткова похідна натурального логарифму результуючої формули (7) за числом $\pi$ (число $\pi$ задається 3 кінцевою кількістю цифр після коми, що вносить похибку [13-17]):

$$
\frac{\partial \ln H B W}{\partial \pi}=-\frac{1}{\pi}
$$

де $\frac{\partial \ln H B W}{\partial k}-$ часткова похідна натурального логарифму результуючої формули (7) за коефіцієнтом перерахунку кг॰с в Н $k$ (число $k$ задається $з$ кінцевою кількістю цифр після коми, що може вносити похибку [13-17]):

$$
\frac{\partial \ln H B W}{\partial k}=-\frac{1}{k}
$$

де $\frac{\partial \ln H B W}{\partial D}-$ часткова похідна натурального логарифму результуючої формули (7) за діаметром індентора $D$ :

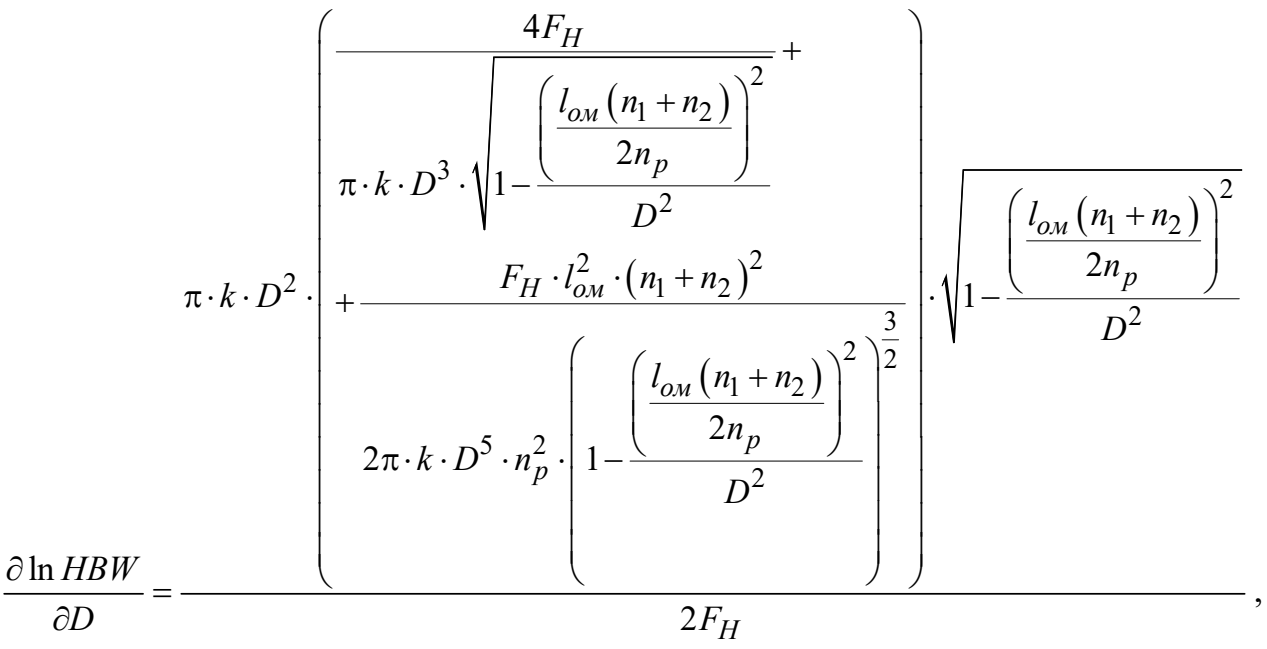

де $\frac{\partial \ln H B W}{\partial l_{\text {мм }}}$ - часткова похідна натурального логарифму результуючої формули (7) за діаметром довжиною об’єкт мікрометру, $l_{\text {ом }}$, що задана оператором при юстуванні оптичної системи:

$$
\frac{\partial \ln H B W}{\partial l_{\text {ом }}}=\frac{l_{\text {ом }}\left(n_{1}+n_{2}\right)^{2}}{4 D^{2} \cdot n_{p}^{2} \cdot\left(\frac{\left(\frac{l_{O M}\left(n_{1}+n_{2}\right)}{2 n_{p}}\right)^{2}}{D^{2}}-1\right)}
$$

де $\frac{\partial \ln H B W}{\partial n_{1}}-$ часткова похідна натурального логарифму результуючої формули (7) за кількістю пікселів між горизонтальними маркерами, $n_{1}$ :

$$
\frac{\partial \ln H B W}{\partial n_{1}}=\frac{l_{\text {OM }}^{2}\left(2 n_{1}+2 n_{2}\right)}{8 D^{2} \cdot n_{p}^{2} \cdot\left(\frac{\left(\frac{l_{\text {OM }}\left(n_{1}+n_{2}\right)}{2 n_{p}}\right)^{2}}{D^{2}}-1\right)},
$$

де $\frac{\partial \ln H B W}{\partial n_{2}}-$ часткова похідна натурального лога- рифму результуючої формули (7) за кількістю пікселів між вертикальними маркерами, $n_{2}$ :

$$
\frac{\partial \ln H B W}{\partial n_{2}}=\frac{l_{O M}^{2}\left(2 n_{1}+2 n_{2}\right)}{8 D^{2} \cdot n_{p}^{2} \cdot\left(\frac{\left(\frac{l_{O M}\left(n_{1}+n_{2}\right)}{2 n_{p}}\right)^{2}}{D^{2}}-1\right)},
$$

де $\frac{\partial \ln H B W}{\partial n_{p}}-$ часткова похідна натурального логарифму результуючої формули (7) за кількістю пікселів, $n_{p}$, на отриманому цифровому зображенні, що відповідають заданій довжині об'єкт мікрометру $\left(l_{\text {ом }}\right)$, при юстуванні оптичної системи:

$$
\frac{\partial \ln H B W}{\partial n_{p}}=-\frac{l_{\text {ом }}^{2}\left(n_{1}+n_{2}\right)^{2}}{4 D^{2} \cdot n_{p}^{3} \cdot\left(\frac{\left(\frac{l_{\text {ом }}\left(n_{1}+n_{2}\right)}{2 n_{p}}\right)^{2}}{D^{2}}-1\right)}
$$

Аналіз складових похибки визначення твердості

Загальний аналіз складових похибки визначення 
твердості:

1) $\Delta_{F_{H}}$ - похибка обумовлена застосовуваним обладнанням при випробуванні зразка на твердість. Зазначена складова похибки занормована вимогами ISO 6506 [1-4] на рівні не більше $\pm 1 \%$ від заданого зусилля. Усунення повністю - неможливо. Може бути оцінена зі свідоцтва про повірку / сертифікату про калібрування відповідного обладнання. Шляхи зменшення - використання більш точного обладнання;
2) $\Delta_{\pi}$ - систематична похибка, обумовлена обмеженням кількості цифр після коми числа $\pi$. Усунення повністю - неможливо. Шляхи зменшення збільшення кількості цифр після коми.

На рис. 3 приведена залежність абсолютного значення відносної похибки розрахованої згідно 3 коефіцієнтом (19) та розрахованого значення $\Delta_{\pi}$ в залежності від кількості цифр після коми для числа $\pi$ [13-17].

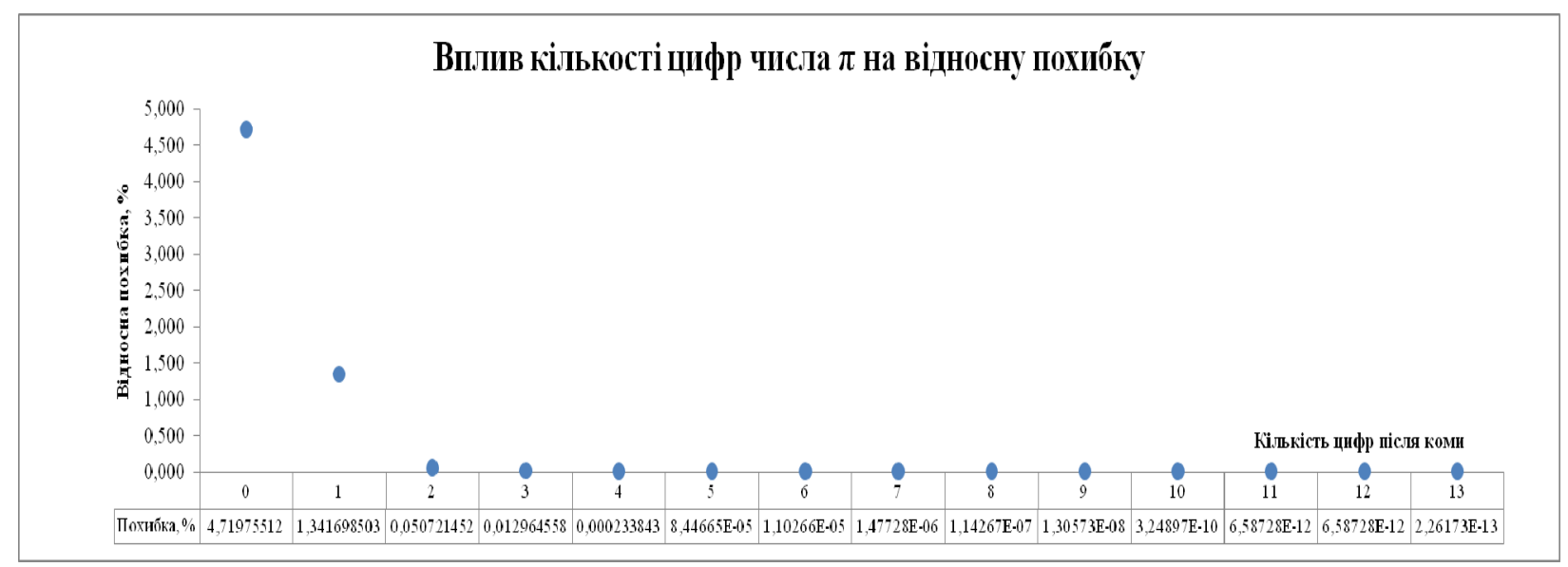

Рис. 3. Залежність абсолютного значення відносної похибки від кількості цифр після коми для числа $\pi$ Джерело: розроблено авторами.

Як видно з рис. 3 похибка, обумовлена обмеженням кількості цифр після коми для числа $\pi$ стає нехтовно малою вже після врахуванні п'ятого знаку після коми [13-17]. В більшості платформ для розрахунків число $\pi$ наявне в стандартному наборі функцій, приклади кількості цифр після коми для числа $\pi$ наведено у табл. 1.

Точність визначення числа $\pi$ для різних платформ

\begin{tabular}{|c|c|c|}
\hline $\begin{array}{c}\text { Платформа } \\
\text { (середовище } \\
\text { програмування) }\end{array}$ & $\begin{array}{c}\text { Функція } \\
\text { / конс- } \\
\text { танта }\end{array}$ & $\begin{array}{c}\text { Значення } \pi \\
\text { (кількість цифр } \\
\text { після коми) }\end{array}$ \\
\hline MS Excel 2007 & ПИ() & 3,141592654 (9) \\
\hline $\begin{array}{c}\text { C/C++ } \\
\text { (бібліотека } \\
\text { math.h) }\end{array}$ & M_PI & $\begin{array}{c}3.1415926535897932 \\
3846(20)\end{array}$ \\
\hline LabVIEW & $\begin{array}{c}\text { Pi } \\
\text { constant }\end{array}$ & $\begin{array}{c}3.1415926535897932 \\
(16)\end{array}$ \\
\hline MathCAD & - & $>100$ цифр \\
\hline $\begin{array}{c}\text { Pуthon } \\
\text { (бібліотека } \\
\text { math) }\end{array}$ & math.pi & $\begin{array}{c}3.141592653589793 \\
(15)\end{array}$ \\
\hline
\end{tabular}

Джерело: розроблено авторами за даними [13-17].

Отже, зазначена систематична похибка стає нехтовно мала, та може не враховуватися (при достатній кількості цифр після коми, або застосування стандартних функцій [13-17]);

3) $\Delta_{k}$ - систематична похибка, обумовлена обмеженням кількості цифр після коми.

Можливе повне усунення шляхом уточнення значення коефіцієнту $k=9,80665$ [точно] Н/кгс, або використанні обладнання, що задає зусилля одразу в кг'с.

На рис. 4 приведена залежність абсолютного значення відносної похибки розрахованої згідно 3 коефіцієнтом (20) та розрахованого значення $\Delta_{k}$ в залежності від кількості цифр після коми (на випадок, якщо хтось у XXI столітті бажає зекономити на пам'яті обчислювальних систем) [13-17];

4) $\Delta_{D}-$ похибка обумовлена застосовуваним обладнанням при випробуванні зразка на твердість. Зазначена складова похибки занормована вимогами

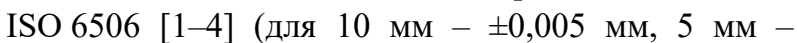
$\pm 0,004$ мм, 2,5 мм - $\pm 0,003$ мм, 1 мм - $\pm 0,003$ мм). Усунення повністю - неможливо. Може бути оцінена зі свідоцтва про повірку / сертифікату про калібрування відповідного обладнання. Шляхи зменшення - використання більш точного обладнання;

5) $\Delta_{l_{\text {oм }}}$ - похибка обумовлена застосовуваним обладнанням (об'єктом мікрометром) при юстуванні оптичної системи. Усунення повністю - неможливо. Може бути оцінена зі свідоцтва про повірку / сертифікату про калібрування відповідного обладнання (об'єкту мікрометра). Шляхи зменшення - використання більш точного обладнання та більш точного калібрування; 


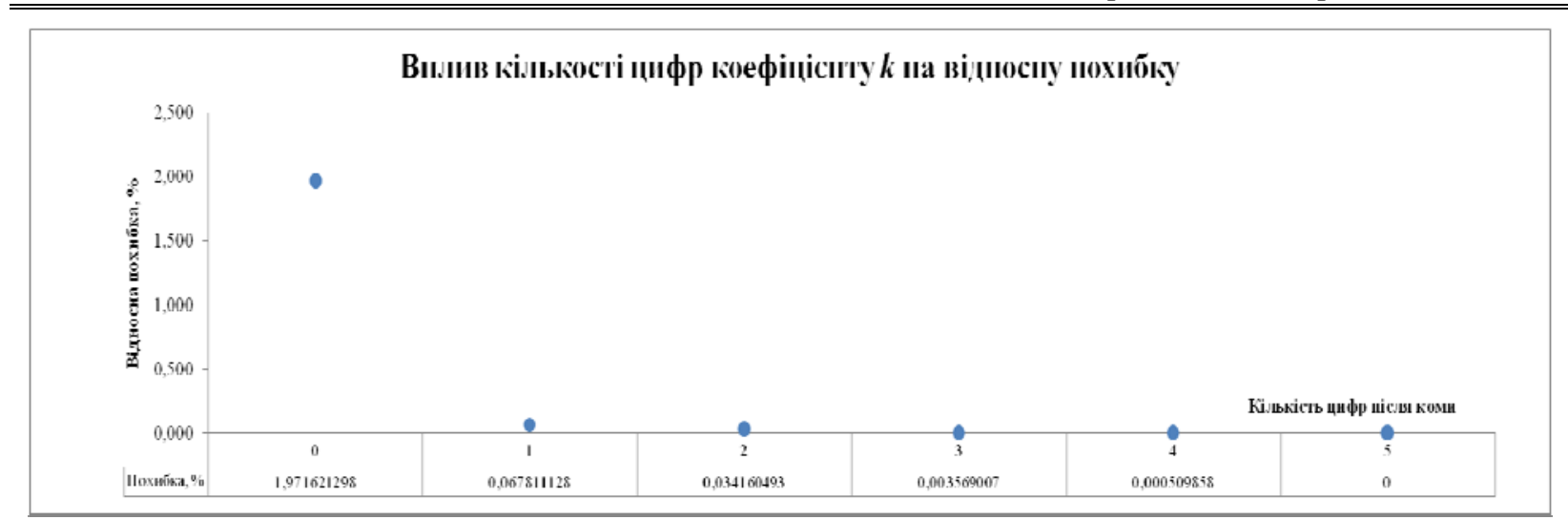

Рис. 4. Залежність абсолютного значення відносної похибки від кількості цифр після коми для коефіцієнту $k$ Джерело: розроблено авторами.

6) $\Delta_{n_{1}}, \Delta_{n_{2}}-$ похибки, обумовлені діяльністю оператора, обмеженням роздільної здатності оптичної системи, неможливістю точного визначення меж відбитку, тощо.

Оцінювання - індивідуальне для кожного випадку, для розрахунку похибки, можуть прийматися рівними одному пікселю (не враховує похибку, що вносить оператор і неможливість точного визначення меж відбитку).

Шляхи зменшення - навчання оператора, використання більш точного обладнання (збільшення роздільної здатності оптичної системи), застосування освітлювального обладнання для отримання більш контрастного зображення, тощо;

7) $\Delta_{n_{p}}$ - похибка, обумовлена діяльністю оператора, обмеженням роздільної здатності оптичної системи, неможливістю точного визначення меж об’єкта мікрометру, відхилення з'єднувальної лінії від перпендикуляру, тощо.

Оцінювання - індивідуальне для кожного випадку, для розрахунку похибки, що вносить ПЗ ЗВТ, можливе мінімальне значення - один піксел (врахування тільки похибки, що обумовлена обмеженням роздільної здатності оптичної системи).

Шляхи зменшення - навчання оператора, використання більш точного обладнання (збільшення роздільної здатності оптичної системи), застосування освітлювального обладнання для отримання більш контрастного зображення, підбір оптимальної фокусної відстані, тощо.

\section{Висновки}

На основі положень міжнародного стандарту ISO 6506 [1-4] створено загальний алгоритм для визначення твердості за Брінеллем для вимірювальних приладів з оптичною системою, отримана результую- ча формула для розрахунку твердості за Брінеллем, яка враховує вісім різних складових похибок. Теоретичний аналіз основних складових похибки визначення твердості за методом Брінелля дає змогу стверджувати, що:

1) наявні три складових похибки, що обумовлені застосовуваним обладнанням при випробуванні зразка $\left(\Delta_{F_{H}}, \Delta_{D}, \Delta_{l_{\text {ом }}}\right)$, для яких шлях мінімізації полягає у використанні більш точного обладнання та метрологічного забезпечення, усунення повністю неможливе, межі занормовані у ISO 6506 [1-4];

2) наявні три складових похибки, що обумовлені діяльністю оператора та обмеженням роздільної здатності оптичної системи ( $\left.\Delta_{n_{1}}, \Delta_{n_{2}}, \Delta_{n_{p}}\right)$, для яких шлях мінімізації полягає у навчанні операторів, використанні більш точного обладнання (збільшення роздільної здатності оптичної системи), застосуванні освітлювального обладнання для отримання більш контрастного зображення, тощо, усунення повністю неможливе, максимальні значення не занормовані та повинні оцінюватися безпосередньо при випробуванні зразка на твердість;

3) наявні дві систематичні складових похибки, що обумовлені обмеженням кількості цифр після коми $\left(\Delta_{\pi}, \Delta_{k}\right)$, для яких шлях мінімізації полягає у збільшення кількості цифр після коми, для $\Delta_{k}$ можливе повне усунення шляхом уточнення значення коефіцієнту $k=9,80665$ [точно] $\mathrm{H} /$ кгс, для $\Delta_{\pi}$ можливо досягти нехтовно малих значень, та може не враховуватися (при достатній кількості цифр після коми, або застосування стандартних функцій) [13-17].

Практичні досліди 3 прикладами розрахунків і мінімізації похибок при визначенні твердості за Брінелем будуть приведені у наступних публікаціях.

\section{Список літератури}

1. ISO 6506-1:2014. Metallic materials - Brinell hardness test - Part 1: Test method. [Publication date 2014-10]. Official publication. Geneva, Switzerland : ISO, 2014. 16 p. 
2. ISO 6506-2:2017. Metallic materials - Brinell hardness test - Part 2: Verification and calibration of testing machines. [Publication date 2017-10]. Official publication. Geneva, Switzerland : ISO, 2017. 16 p.

3. ISO 6506-3:2014. Metallic materials - Brinell hardness test - Part 3: Calibration of reference blocks. [Publication date 2017-10]. Official publication. Geneva, Switzerland : ISO, 2014. 10 p.

4. ISO 6506-4:2014. Metallic materials - Brinell hardness test - Part 4: Table of hardness values. [Publication date $2014-$ 10]. Official publication. Geneva, Switzerland : ISO, 2014. 11 p.

5. Reichardt A., Shapiro A., Otis R., Dillon R., Borgonia J., McEnerney B., Hosemann P., Beese A. Advances in additive manufacturing of metal-based functionally graded materials. International Materials Reviews. 2020. Vol. 66. No. 1. P. 1-29. https://doi.org/10.1080/09506608.2019.1709354.

6. Марковец М. П. Определение механических свойств металлов по твердости. Москва : Машиностроение, 1979. $191 \mathrm{c}$.

7. Коржов І. М. Пристрій контролю та діагностування стану промислових динамічних об’єктів : дис. ... д-ра філософії : 152. Національний технічний університет “Харківський політехнічний інститут”. Харків, 2019. 304 с.

8. Бабіченко А. К., Кравченко Я. О., Вельма В. І., Накостенко В. В. Особливості ідентифікації об'єктів керування 3 великою інерційністю. Науково-практичні засади загально-інженерної підготовки фахівців фармації : зб. наук. пр. I міжнар. наук.-практ. інтернет-конф., м. Харків, 25-26 жовт. 2018 р. Харків : НФаУ, 2018. С. 26-28.

9. Коржов І. М. Перспективи розвитку теорії і практики контролю та діагностування в розрізі перевірки кваліфікації лабораторій. Вісник Національного технічного університету “ХІІІ”. 2018. № 27(1303). С. 30-34.

10. Gurland J. New scientific approaches to development of tool materials. International Materials Reviews. 1988. Vol. 33. No. 1. P. 151-166. https://doi.org/10.1179/imr.1988.33.1.151.

11. Tabor D. The Hardness of Metals. New York : Oxford University Press, 2000. 175 p.

12. Орешко Е. И., Уткин Д. А., Ерасов В. С., Ляхов А. А. Методы измерения твердости материалов (обзор). Tруды Всероссийского научно-исследовательского института авиационных материалов. $2020 . \quad$ № $1 . \quad$ С. $101-117$. https://doi.org/10.18577/2307-6046-2020-0-1-101-117.

13. Коржов I. М., Тверитникова О. Е. Вплив програмного забезпечення на сумарну похибку цифрових засобів вимірювальної техніки. Інформачійні технологї̈: наука, техніка, технологія, освіта, здоров'я (МіскоСAD-2016) : зб. наук. пр. XXIV міжнар. наук.-практ. конф., м. Харків 18-20 травня 2016 р. Харків : НТУ “ХПІ”, 2016. Ч. 2. С. 68.

14. Babichenko A., Kravchenko Y., Babichenko J., Krasnikov I., Lysachenko I., Velma V. Algorithmic tools for optimizing the temperature regime of evaporator at absorption refrigeration units of ammonia production. Eastern-European Journal of Enterprise Technologies. 2018. Vol. 4. No. 2 (94). P. 29-35.

15. Gorkunov B., Lvov S., Borysenko Y., Shamardina V., Nour S.A., Chorna O. Application of Electromagnetic Transducer for Noncontact Monitoring of Shaft Torque in Electromechanical Systems. IEEE Problems of Automated Electrodrive. Theory and Practice (PAEP) : conference paper. IEEE, 2020. P. 1-4. https://doi.org/10.1109/PAEP49887.2020.9240804.

16. Никонов О. Я., Мнушка О. В., Савченко В. Н. Оценка точности вычислений специальных функций при разработке компьютерных программ математического моделирования. Вестник национально-технического университета “Харьковский политехнический институт”. 2011. № 17. С. 115-121.

17. Бакаева О. А. Сравнительный анализ методов вычисления числа Пи стандартными средствами. Программные продукты и системы. 2018. № 2. С. 409-413. https://doi.org/10.15827/0236-235X.122.409-413.

Надійшла до редколегії 20.10.2021

Схвалена до друку 16.11.2021

\section{Відомості про авторів:}

\section{Коржов Ігор Михайлович}

кандидат технічних наук

інженер Державного підприємства

"Харківський регіональний науково-виробничий центр стандартизації, метрології та сертифікації”,

Харків, Україна

https://orcid.org/0000-0003-2315-2683

\section{Кравченко Яна Олегівна}

кандидат технічних наук

Національного технічного університету

“Харківський політехнічний інститут”,

Харків, Україна

https://orcid.org/0000-0002-6311-8060

\section{Борисенко Свген Анатолійович}

кандидат технічних наук

Національного технічного університету

“Харківський політехнічний інститут”,

Харків, Україна

https://orcid.org/0000-0001-7511-2590

\section{Information about the authors:}

\section{Ihor Korzhov}

$\mathrm{PhD}$ in Engineering

Engineer of State Enterprise

"Kharkov Regional Research and Production Center

for Standardization, Metrology and Certification",

Kharkiv, Ukraine

https://orcid.org/0000-0003-2315-2683

Yana Kravchenko

$\mathrm{PhD}$ in Engineering

of National Technical University

"Kharkiv Polytechnic Institute",

Kharkiv, Ukraine

https://orcid.org/0000-0002-6311-8060

\section{Yevhen Borysenko}

$\mathrm{PhD}$ in Engineering

of National Technical University

"Kharkiv Polytechnic Institute",

Kharkiv, Ukraine

https://orcid.org/0000-0001-7511-2590 


\title{
АНАЛИЗ ОСНОВНЫХ СОСТАВЛЯЮЩИХ ПОГРЕШНОСТИ ОПРЕДЕЛЕНИЯ ТВЕРДОСТИ ПО МЕТОДУ БРИНЕЛЛЯ С ИСПОЛЬЗОВАНИЕМ ОПТИЧЕСКИХ СИСТЕМ
}

\author{
И.М. Коржов, Я.О. Кравченко, Е.А. Борисенко
}

В статье приведен общий алгоритм определения твердости по Бринеллю для измерительных приборов с оптической системой на основе положений международного стандарта ISO 6506, получена результирующая формула для расчета твердости по Бринеллю для измерительных приборов с оптической системой. На основе результирующей формуль для расчета твердости получены и проанализированы абсолютная и относительная погрешность, а также их составляющие. Приведен теоретический анализ основных величин, влияюших на точность определения твердости методом Бринелля и пути их уменьшения для измерительных приборов с программным обеспечением для расчетов и оптической системой для измерения параметров отпечатка индентора. Приведенный теоретический анализ составляющих погрешностей определения твердости методом Бринелля и пути их уменьшения позволяет более подробно оценить погрешность определения твердости и минимизировать влияние некоторых составляющих соответствующего оборудования для измерения твердости.

Ключевые слова: твёрдость, метод Бринелля, твердомеры с оптической системой, метрологическое обеспечение, анализ погрешности.

\section{ANALYSIS MAIN COMPONENTS ERROR BRINELL DETERMINATION OF HARDNESS USING OPTICAL SYSTEMS}

I. Korzhov, Ya. Kravchenko, Ye. Borysenko

Hardness is one of the physical and mechanical properties of structural materials that determines their quality, especially for metals and their alloys. Hardness is the ability of a material to resist deformation and, as a consequence, fracture. The hardness of a metal can indirectly assess its other properties, due to the dependence of hardness on the internal structure of the material. In connection with the constant increase in requirements for the quality of industrial products, both in the domestic and world markets, there is a constant strengthening of control conditions for input raw materials, including metal and metal products, which in turn leads to the need for careful metrological control of input raw materials and in particular the determination of hardness. Based on the provisions of the international standard ISO 6506, a general algorithm for determining the Brinell hardness for measuring instruments with an optical system was created, the resulting formula for calculating the Brinell hardness for measuring instruments with an optical system was obtained. Based on the resulting formula for calculating Brinell hardness for measuring instruments with an optical system, the absolute and relative error, as well as its components are obtained and analyzed. The article presents a theoretical analysis of the main values that affect the accuracy of Brinell hardness determination and ways to reduce them for measuring instruments using calculation software and optical systems. The presented theoretical analysis of the main components of Brinell hardness determination errors and ways to reduce them allows to estimate the hardness error in more detail and minimize the impact of some components, especially at the design stage of appropriate Brinell hardness measuring equipment for measuring instruments for measuring indenter fingerprint parameters.

Keywords: hardness, Brinell method, hardness testers with optical system, metrological support, error analysis. 